\title{
A review of M. A. K. Halliday, Aspects of Language and Learning
}

Hui Yu(D)

Correspondence: yuh@bnu.edu.cn School of Foreign Languages and Literature, Beijing Normal University, Beijing 100875, China

\begin{abstract}
This volume was published as one of the "M.A.K. Halliday Library Functional Linguistics" Series. It is based on a series of lectures given by Professor Halliday at the National University of Singapore in 1986. The theme of these lectures is to construct a linguistically informed theory of education, providing a linguistic interpretation of how people learn. The lectures as a whole provide an essential framework of Halliday's ideas on language, knowledge and education.
\end{abstract}

Chapter one, "Language, Learning and 'Educational Knowledge", aims to demonstrate that the process of learning is itself a linguistic process. To do that, Halliday traces back to the very beginning of the learning process, the ontogenetic beginning of a human child. By observing how a human infant develops his own protolanguage, Halliday is able to show that a child not only uses language to express, but also to act, the two functions corresponding to what he calls the ideational and interpersonal metafunctions of language. The linguistic and the learning ability of the child keep developing until he meets a new challenge when he goes to school: the transition from "commonsense knowledge" to "educational knowledge".

Chapter two, "The Evolution of a Language of Science", explores the language of science from a diachronic perspective. The aim of the research is by nature educational. As children move from commonsense knowledge to educational knowledge, they may have difficulties with educational discourse. The task of the linguist is to identify the nature of the linguistic demands that are imposed on children. In this chapter, Halliday does this by examining how the language of science has evolved. Four classical scientific passages from the fourteenth century to the nineteenth century are analyzed and compared with a span over 400 years. The result of the comparison shows a tendency towards the packaging of information and abstraction. It is such features that set apart educational discourse from everyday, commonsense discourse.

Chapter three, "Learning to Learn Through Language", starts with a brief discussion on the possibility of applying linguistics to early childhood education. Research has shown a child is able to develop his protolanguage for his own purposes. A further account of children's "language diary" shows children are also using their language to learn. Even though what factors contribute to children's learning ability is not yet clear, children's preschool experience of spoken language plays an important part in their education in school. Seven general principles are suggested on which children's learning ability must be founded. The gap between children's preschool language and the

(C) 2016 The Author(s). Open Access This article is distributed under the terms of the Creative Commons Attribution 4.0 International License (http://creativecommons.org/licenses/by/4.0/), which permits unrestricted use, distribution, and reproduction in any medium, provided you give appropriate credit to the original author(s) and the source, provide a link to the Creative Commons license, and indicate if changes were made. 
scientific discourse in school is not as wide as generally assumed. There exists a continuity between the two, the latter of which is further discussed in the next chapter.

Chapter four, "Language and Learning in the Primary School", explores the learning process from four perspectives: initial literacy, style and registers in the primary school, the beginnings of scientific discourse, spoken and written language in education. When children begin their school education, they have to call up experiences stored previously, to help them learn to read and write. There is much more to children's writing ability than just writing a narrative. Children should also learn to write other types of writing including scientific discourse, for they learn, not just scientific knowledge, but also the language in which knowledge is presented. In the process, children gradually become aware of the differences between spoken language and written language, i.e. the grammatical intricacy of the spoken language vs. the lexical density of the written language. Specifically how subject-oriented learning takes place is further explored in the next chapter.

Chapter five, "The Language of School 'Subjects" investigates another stage of learning. As children move on to secondary school, they begin to work with different school subjects. The task of educational linguistics is not just to describe the language of subject learning, but also to explain it regarding the way language is used. Teaching environment is not restricted to classroom, but takes various forms including textbook, library research, homework and so on, in which the field is the same, but the tenor and the mode are different. It is the tenor and the mode, rather than the field that sets the patterns of teaching. The analysis of how the discourse matches up to the context shows that every teacher is a teacher of language, which is to say all learning is a linguistic process.

Chapter six, "English and Chinese: Similarities and Differences", approaches the issue of language and education from a comparative point of view. All human babies are alike in that they develop a system of their own protolanguage despite the differences in their mother tongue. It may be a stage comparable to an earlier phase in the evolution of human language. Observation of children's transition into the mother tongue shows important similarities with their mode of entry into the language. The mode of learning for English-speaking and Chinese-speaking children is essentially the same. Speaking different mother tongues does not create significant differences regarding children's understanding of school subjects. There do exist significant differences between English and Chinese which may create different learning experiences for learners. Nevertheless, both languages will develop in the same direction due to pressure from social and technical development.

Chapter seven, "Languages and Cultures", provides an even broader picture of language and learning. Complex patterns of English in Singapore are described. Examples from different languages are also cited and analyzed to further illustrate the relationship between language and culture. The aim is to draw on general principles relating to language and learning.

Chapter eight, "Language, Education and Science: Future Needs", is the last lecture given in this series of talks in Singapore. It rounds off the lectures by not only summarizing the previous talks, but also pointing out directions toward which educational linguistics should develop. At the end of the lecture, Halliday draws attention to an emerging research frontier, the increasing contact between linguistics and natural science. 


\section{Conclusion}

Throughout the lectures, Halliday has been trying to present the perspective that learning is a linguistic process. Learning is not simply learning the knowledge of the subject. Rather, it is more about learning how the knowledge of the subject is codified and transmitted via language. It is therefore important for a linguist to explain how language functions in the process of education. To answer that, at least three questions should be asked: (1) How is knowledge organized through language? (2) How does language help students to learn? (3) What does the teacher need to know about language in order to help students along their learning process? These lectures were given 30 years ago in a Singapore context. Nonetheless, throughout the last three decades, these questions have constantly been asked, addressed and answered.

Relevant studies range from uncovering the nature of science discourse and investigating science literacy in primary and secondary school (Halliday and Martin 1993), to raising teachers' awareness about language challenges (Schleppegrell and de Oliveira 2006). The fruitful dialogue between Bernstein's sociology of education and Halliday's systemic functional linguistics has led to an even great interest in the study on language, knowledge and education (Martin and Veel 1998; Christie and Martin 2007; Martin and Rose 2007; Rose and Martin 2012; Maton 2013). In all these studies, language is put "squarely in the centre of the picture" (149). The quest for the nature of language and learning is going to continue for a long time to come.

Competing interests

The author declares that he/she has no competing interests.

Received: 16 August 2016 Accepted: 16 September 2016

Published online: 22 September 2016

\section{References}

Christie, F., and J.R. Martin (eds.). 2007. Language, knowledge and pedagogy: Functional linguistic and sociological perspectives. London: Continuum.

Halliday, M.A.K., and J.R. Martin. 1993. Writing science: Literacy and discourse power. London: Falmer Press.

Martin, J.R., and D. Rose. 2007. Genre relations: Mapping culture. London: Equinox.

Martin, J.R., and R. Veel (eds.). 1998. Reading science: Critical and functional perspectives on discourse of science. New York: Routledge.

Maton, K. 2013. Knowledge and knowers: Towards a realist sociology of education. London \& New York: Routledge.

Rose, D., and J.R. Martin. 2012. Learning to write, reading to learn: Genre, knowledge and pedagogy in the Sydney school. London: Equinox.

Schleppegrell, M., and L. de Oliveira. 2006. An integrated language and content approach for history teachers. Journal of English for Academic Purposes 5: 254-268.

\section{Submit your manuscript to a SpringerOpen ${ }^{\circ}$ journal and benefit from:}

- Convenient online submission

- Rigorous peer review

- Immediate publication on acceptance

- Open access: articles freely available online

- High visibility within the field

- Retaining the copyright to your article

Submit your next manuscript at $>$ springeropen.com 